\title{
Genetic diversity and population structure of Turkish native cattle breeds
}

\author{
Y. Öner ${ }^{1 \#}$, O. Yılmaz ${ }^{2}$, C. Eriş ${ }^{1}$, N. Ata ${ }^{2}$, C. Ünal ${ }^{3}$ \& S. Koncagül ${ }^{4}$ \\ ${ }^{1}$ Department of Animal Science, Biometry and Genetics, Faculty of Agriculture, Bursa Uludag University, \\ TR-16059, Bursa, Turkey \\ ${ }^{2}$ Department of Animal Science, Biometry and Genetics, Faculty of Agriculture, Aydın Adnan Menderes University, \\ TR-09100 Aydın, Turkey \\ ${ }^{3}$ Department of Zootechnics, Faculty of Veterinary Medicine, Bursa Uludag University 16059 Nilufer, Bursa Turkey \\ ${ }^{4}$ Department of Animal Science, Animal Breeding, Faculty of Agriculture, Ankara University 06110, Ankara, Turkey
}

(Received 2 October 2018; Accepted 15 May 2019; First published online 8 July 2019)

\author{
Copyright resides with the authors in terms of the Creative Commons Attribution 4.0 South African License. \\ See: http://creativecommons.org/licenses/by/4.0/za \\ Condition of use: The user may copy, distribute, transmit and adapt the work, but must recognize the authors and \\ the South African Journal of Animal Science.
}

\begin{abstract}
Cattle are an important livestock species for human life, but certain breeds are at risk of extinction. Maintaining genetic diversity plays an important role in sustainable breeding and conservation programmes in farm animals. The aim of this study was to determine genetic diversity among five Turkish native cattle breeds. A total of 199 Turkish native cattle of the Native Southern Yellow $(n=40)$, South Anatolian Red $(n=40)$, Anatolian Grey Cattle $(n=40)$, Native Black Cattle $(n=39)$ and East Anatolian Red $(n=40)$ breeds were investigated using 22 autosomal microsatellite markers. The analysis revealed considerable genetic variation among these breeds. All loci were polymorphic, and a total of 545 alleles were found. Among these loci, only INRA032 was at Hardy-Weinberg equilibrium. Thirty-four private alleles with frequencies greater than $5 \%$ were found. Expected heterozygosity and polymorphic information content indexes were 0.87 and 0.88 , respectively. Native Southern Yellow, South Anatolian Red and Native Black Cattle breeds were closely related.
\end{abstract}

Keywords: animal genetic resources, microsatellite, genetic relationship, genetic conservation

\#Corresponding author: yaseminoner@yahoo.com

\section{Introduction}

All cattle breeds that are used today in the livestock industry are the results of a long domestication process. Domesticated breeds exhibit phenotypic and genetic diversity (Glazko, 2003). Maintaining this genetic diversity is needed to meet current and future production demand and attain sustainable animal production (Notter, 1999).

Cattle are suitable for domestication owing to their ability to sense feeding facilities and to attain a favourable growth rate, and because their behavioural traits make them easy to handle (Diamond et al., 1997; Price, 2000). Several cattle breeds have already become extinct, and many face the threat of extinction owing to the predominant use of imported cattle breeds such as Holstein Friesian in milk production systems (Notter, 1999). Estimating and monitoring genetic variation between and within populations may contribute to designing more rational and sustainable breeding and conservation programmes by estimating the degree of inbreeding and risk status. Conservation of genetic diversity is a type of guarantee against possible unexpected environmental conditions because it is a means of maintaining potential adaptation abilities (Toro \& Caballero, 2005). Furthermore, examination of genetic diversity may help to reveal human historical movements (Loftus et al., 1999). Today, Anatolia is recognized as a domestication centre for cattle and other livestock species (Zeder, 2008). Native Southern Yellow (NSY), South Anatolian Red (SAR), Anatolian Grey Cattle (AGC), Native Black Cattle (NBC), East Anatolian Red (EAR) and Zavot are native Turkish cattle breeds that were registered officially by the Republic of Turkey Ministry of Agriculture and Forestry. Fifteen cattle breeds raised in Anatolia were declared extinct (FAO, 2018) 
Studies have been carried out to investigate genetic variation and genetic relationships among Turkish native cattle breeds by unipaternal markers and autosomal genetic markers. Moreover, these breeds were investigated by $Y$ chromosomal markers (Özşensoy et al., 2014), mtDNA (Özdemir \& Doğru, 2009; Doğan et al., 2017), random amplified polymorphic DNA (RAPD) (Güneren et al., 2010) and microsatellite (Özkan, 2005; Özşensoy et al., 2010) markers. In this study, the authors aimed to estimate the genetic diversity of five Turkish native breeds by autosomal microsatellite markers.

\section{Materials and methods}

The study was approved by the Ethics Committee of Uludag University (UUHADYEK) (approval date: 01/09/2015; no: 2015-10/10).

Samples were obtained in the original geographic regions of the five native breeds (Figure 1). These geographic regions and sample size of each breed are given in Figure 1. Blood samples from 199 animals were collected from the coccygeal veins into tubes containing K3EDTA.

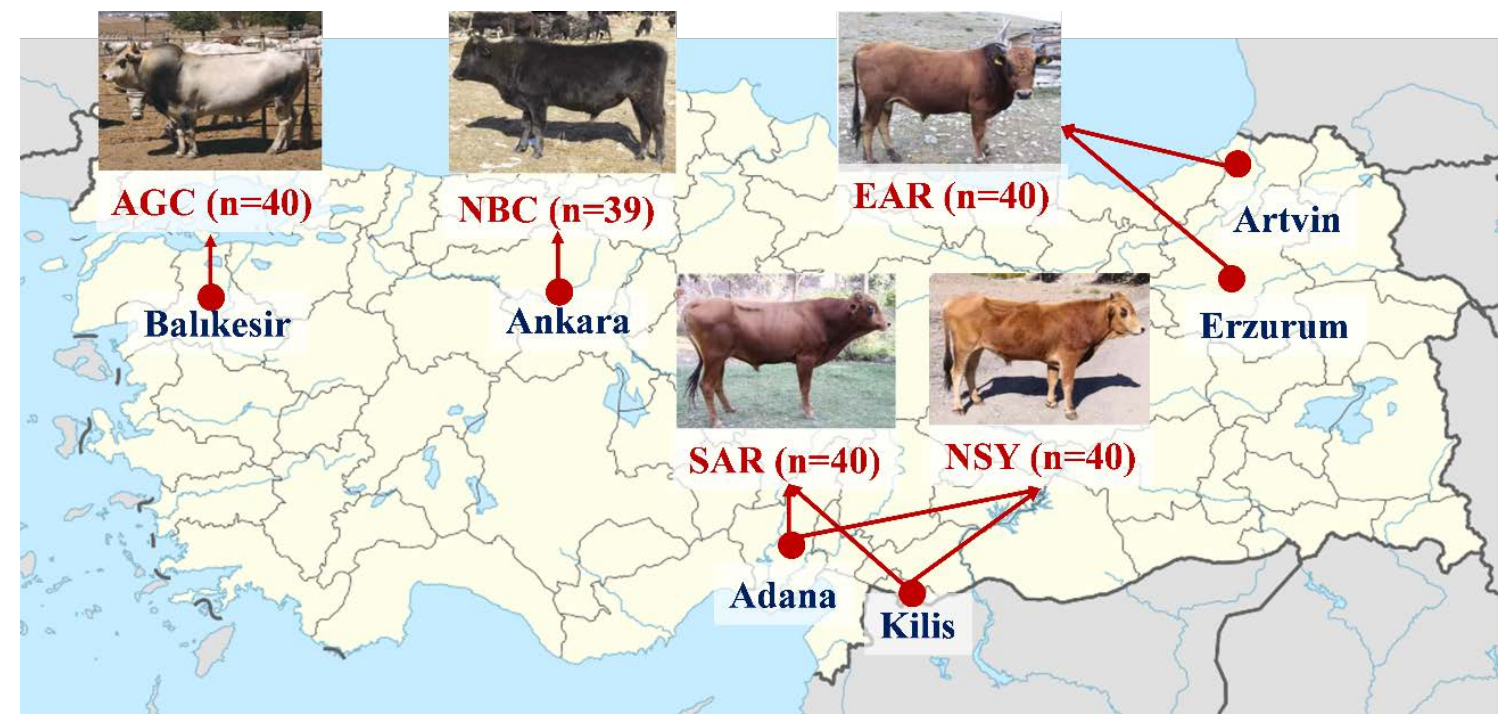

Figure 1 Origin and sample size of five cattle breeds in Turkey NSY: Native Southern Yellow, SAR: South Anatolian Red, NBC: Native Black Cattle, AGC: Anatolian Grey Cattle, EAR: East Anatolian Red

Genomic DNA was extracted from the blood samples with a genomic DNA extraction kit (NucleoSpin Blood, Macherey-Nagel $\mathrm{GmbH}$ \& Co. KG) according to the manufacturer's instructions. Afterwards, quantification and qualification of DNA were performed using a NanoDrop 2000 spectrophotometer (Thermo Scientific, USA). Twenty-two microsatellite markers that were labelled with fluorescent dyes (D2, D3 and D4) were used according to the recommendations of FAO (2011). Two multiplex groups were created according to the fragment length of the microsatellites (Table 1). The total volume of the amplification mixture was 20 $\mu \mathrm{L}$ and it contained $0.1 \mu \mathrm{M} /$ each primer, $0.2 \mathrm{mM}$ dNTPs (Applied Biological Materials Inc., Canada), $2.5 \mathrm{mM}$ $\mathrm{MgCl}_{2}, 1 \times$ PCR buffer, $1 \cup$ Taq DNA polymerase (New England Biolabs (NEB), USA) and $\sim 50 \mathrm{ng}$ of genomic DNA. Genomic DNA was amplified by the touchdown PCR technique with the multiplex microsatellite group that was reported by Hecker \& Roux (1996). Capillary electrophoresis was used for the separation of the PCR fragments labelled with the fluorescent dyes using the Beckman Coulter GeXP genetic analysis system (Beckman Coulter, Inc., USA). GenomeLab ${ }^{\text {TM }}$ DNA size standard kit 400 was used to determine fragment sizes.

The number of alleles per locus $(\mathrm{Na})$, mean number of alleles $(\mathrm{MNa})$, effective number of alleles $(\mathrm{Ne})$, observed heterozygosity ( $\mathrm{Ho}$ ), expected heterozygosity $(\mathrm{He})$ and Hardy-Weinberg equilibrium were calculated with GenAIEx (Peakall \& Smouse, 2006, Peakall \& Smouse, 2012) and POPGENE 1.32 (Yeh et al., 1997). Polymorphic information content (PIC) and null allele frequencies were calculated using CERVUS 3.0.3 (Marshall et al., 1998; Kalinowski et al., 2007), while Wright's F-statistics ( $F_{I T}, F_{I S}, F_{S T}$ ) (Weir \& Cockerham, 1984; Wright, 1990) were obtained with POPGENE 1.32 (Yeh et al., 1997). FSTAT version 2.9.3 software (Goudet, 2001) was used to obtain genetic diversity statistics such as Nei's gene diversity $\left(H_{T}\right)$, diversity between breeds $\left(D_{S T}\right)$, and coefficient of gene differentiation $\left(G_{S T}\right)$. Population 1.2.32 (Langella, 1999) and FigTree 1.4.2. (Rambout, 2006) software were used to generate phylogenetic trees 
between breeds according to Nei's Da distance matrix with Nei et al., (1983). The robustness of the dendrogram topology was tested by bootstrap resampling $(n=1000)$.

Table 1 Thermal cycling conditions according to Touchdown Polymerase Chain Reaction

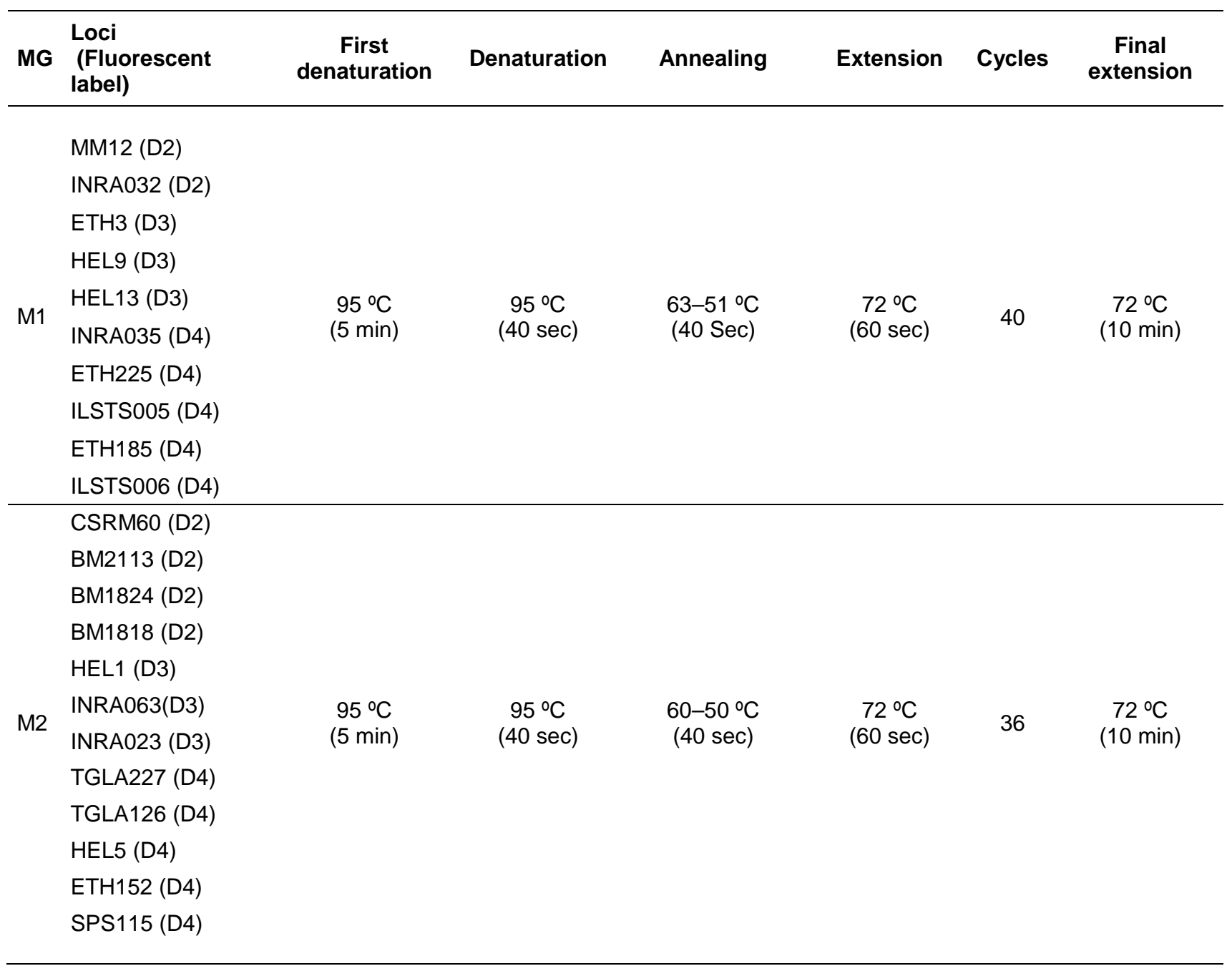

MG: multiplex group

Analysis of molecular variance (AMOVA), which is a method of detecting population differentiation utilizing molecular markers, was performed with ARLEQUIN package version 3.5.2.2 (Excoffier \& Lischer, 2010). STRUCTURE software, which includes cluster techniques based on the Bayesian approach, was used to analyse population structures (Pritchard et al., 2000; Falush et al., 2003, Falush et al., 2007; Hubisz et al., 2009). The population structure analysis was performed using independent allele frequencies and an admixture model (burn of 20000 , followed by $100000 \mathrm{MCMC}$ iterations with 20 replicate runs for each $\mathrm{K}$ ).

The appropriate number of clusters was identified using $\Delta \mathrm{K}$ values that expressed the proportion of alteration in the logarithmic probability $\operatorname{Pr}(\mathrm{X} \mid \mathrm{K})$ of data between $\mathrm{K}$ values according to a method $(\Delta \mathrm{K}=\mathrm{m}|\mathrm{L} "(\mathrm{~K})| \mathrm{s}[\mathrm{L}(\mathrm{K})])$ reported by Evanno et al. (2005). The most suitable $\mathrm{K}$ value was determined according to the $\Delta K$ value calculated by the STRUCTURE harvester program (Earl \& Vonholdt, 2012). The CLUMPAK program reported by Kopelman et al. (2015) was used to find the best alignment from the STRUCTURE results.

\section{Results}

Fragment analysis of 22 microsatellite loci revealed 545 alleles and polymorphism statistics for whole population (Table 2). PIC values $(>0.5)$ indicated that all the microsatellites that were used in the present study were highly informative (Table 2). The number of alleles (Na) ranged from 19 (TGLA126) to 29 
(INRA032). The greatest PIC (0.92) was observed for the TGLA227, HEL5 and INRA035 loci, and TGLA227 had the greatest effective number of alleles $(\mathrm{Ne})$ (13.75). Expected heterozygosity $(\mathrm{He})$ varied between 0.76 (ILSTS005) and 0.93 (TGLA227), and average heterozygosity $(\hat{H})$ was 0.80 . Wright's F statistics were $0.020,0.070$ and 0.088 for $F_{I S}, F_{I T}$, and $F_{S T}$, respectively. $D_{S T}, G_{S T}$ and $H_{T}$ were $0.068,0.078$ and 0.879 , respectively. Only the INRA032 locus was at Hardy-Weinberg equilibrium among these loci (Table 2). All five populations exhibited significant deviations from HWE in at least 5 loci (Table 3).

Table 2 Genetic polymorphism parameters at 22 microsatellite loci of five native Turkish cattle breeds

\begin{tabular}{|c|c|c|c|c|c|c|c|c|c|c|c|c|c|c|c|}
\hline Locus & $\mathbf{N}$ & $\mathrm{Na}$ & $\mathrm{Ne}$ & PIC & Ho & $\mathrm{He}$ & $\hat{\mathbf{H}}$ & $\mathrm{F}_{\mathrm{IS}}{ }^{\#}$ & $\mathrm{~F}_{\mathrm{IT}}{ }^{\#}$ & $\mathbf{F}_{\mathbf{S T}}{ }^{\#}$ & $\mathrm{D}_{\mathrm{ST}}$ & $\mathbf{G}_{\mathrm{ST}}$ & $\mathrm{H}_{\mathrm{T}}$ & F(Null) & HWE \\
\hline MM12 & 167 & 28 & 8.92 & 0.88 & 0.87 & 0.89 & 0.81 & -0.077 & 0.014 & 0.084 & 0.065 & 0.073 & 0.891 & 0.0099 & $\star \star \star ~$ \\
\hline INRA032 & 159 & 29 & 10.76 & 0.90 & 0.89 & 0.91 & 0.86 & -0.030 & 0.025 & 0.053 & 0.037 & 0.041 & 0.909 & 0.0124 & ns \\
\hline ETH3 & 199 & 21 & 6.50 & 0.83 & 0.82 & 0.85 & 0.81 & -0.009 & 0.032 & 0.041 & 0.026 & 0.031 & 0.849 & 0.0175 & * \\
\hline HEL9 & 199 & 23 & 4.29 & 0.74 & 0.96 & 0.77 & 0.72 & -0.325 & -0.252 & 0.054 & 0.037 & 0.048 & 0.768 & -0.1330 & $\star \star \star *$ \\
\hline HEL13 & 197 & 28 & 6.08 & 0.82 & 0.83 & 0.84 & 0.71 & -0.169 & -0.001 & 0.144 & 0.114 & 0.136 & 0.835 & -0.0101 & $* * \star$ \\
\hline INRA035 & 166 & 22 & 12.65 & 0.92 & 0.86 & 0.92 & 0.85 & 0.016 & 0.092 & 0.077 & 0.06 & 0.065 & 0.925 & 0.0353 & $\star \star \star *$ \\
\hline ETH225 & 199 & 20 & 8.49 & 0.87 & 0.96 & 0.88 & 0.83 & -0.157 & -0.088 & 0.059 & 0.045 & 0.051 & 0.884 & -0.0489 & 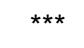 \\
\hline ILSTS005 & 198 & 22 & 4.18 & 0.74 & 0.76 & 0.76 & 0.64 & -0.195 & -0.004 & 0.160 & 0.116 & 0.153 & 0.760 & -0.0004 & $\star \star \star *$ \\
\hline ETH185 & 199 & 25 & 9.96 & 0.89 & 0.64 & 0.90 & 0.84 & 0.237 & 0.291 & 0.071 & 0.053 & 0.059 & 0.902 & 0.1731 & $\star \star * *$ \\
\hline ILSTS006 & 196 & 25 & 8.19 & 0.87 & 0.93 & 0.88 & 0.80 & -0.161 & -0.060 & 0.087 & 0.069 & 0.079 & 0.878 & -0.0295 & $\star * \star$ \\
\hline CSRM60 & 199 & 23 & 7.26 & 0.85 & 0.75 & 0.86 & 0.76 & 0.022 & 0.132 & 0.113 & 0.089 & 0.103 & 0.864 & 0.0743 & $\star \star \star$ \\
\hline BM2113 & 199 & 23 & 10.35 & 0.90 & 0.70 & 0.90 & 0.84 & 0.170 & 0.227 & 0.068 & 0.051 & 0.057 & 0.906 & & $\star \star * *$ \\
\hline BM1824 & 198 & 20 & 7.89 & 0.86 & 0.67 & 0.87 & 0.80 & 0.164 & 0.236 & 0.086 & 0.066 & 0.075 & 0.875 & 0.1371 & 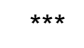 \\
\hline BM1818 & 197 & 23 & 10.08 & 0.89 & 0.86 & 0.90 & 0.84 & -0.028 & 0.042 & 0.068 & 0.052 & 0.058 & 0.902 & 0.0214 & $\star \star \star$ \\
\hline HEL1 & 187 & 22 & 11.78 & 0.91 & 0.91 & 0.92 & 0.84 & -0.078 & 0.010 & 0.081 & 0.064 & 0.069 & 0.919 & 0.0018 & $\star \star \star *$ \\
\hline INRA063 & 198 & 20 & 7.34 & 0.85 & 0.66 & 0.86 & 0.76 & 0.129 & 0.235 & 0.122 & 0.097 & 0.112 & 0.865 & 0.1383 & $\star \star \star *$ \\
\hline INRA023 & 199 & 23 & 10.35 & 0.90 & 0.79 & 0.90 & 0.83 & 0.049 & 0.127 & 0.081 & 0.065 & 0.071 & 0.905 & 0.0675 & $\star \star \star$ \\
\hline TGLA227 & 198 & 24 & 13.75 & 0.92 & 0.90 & 0.93 & 0.88 & -0.027 & 0.031 & 0.056 & 0.043 & 0.046 & 0.930 & 0.0162 & 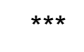 \\
\hline TGLA126 & 150 & 19 & 9.30 & 0.88 & 0.75 & 0.89 & 0.79 & 0.085 & 0.179 & 0.103 & 0.079 & 0.089 & 0.886 & 0.0916 & $\star \star * *$ \\
\hline HEL5 & 187 & 24 & 13.12 & 0.92 & 0.87 & 0.92 & 0.81 & -0.067 & 0.067 & 0.125 & 0.107 & 0.116 & 0.924 & 0.0318 & $\star \star \star *$ \\
\hline ETH152 & 199 & 22 & 9.11 & 0.88 & 0.79 & 0.89 & 0.81 & 0.027 & 0.109 & 0.084 & 0.067 & 0.075 & 0.892 & 0.0592 & $\star \star \star *$ \\
\hline SPS115 & 199 & 23 & 7.38 & 0.86 & 0.79 & 0.86 & 0.77 & -0.022 & 0.088 & 0.108 & 0.085 & 0.099 & 0.866 & 0.0478 & 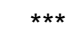 \\
\hline Mean & & 23.14 & 8.99 & 0.87 & 0.82 & 0.88 & 0.80 & -0.020 & 0.070 & 0.088 & 0.068 & 0.078 & 0.879 & & \\
\hline
\end{tabular}

$\mathrm{Na}$ : number of alleles; Ne: effective number of alleles; PIC: polymorphic information content; \#: Wright's statistics according to Weir \& Cockerham (1984); Ho: observed heterozygosity; He: expected heterozygosity; $\hat{\mathrm{H}}$ : average heterozygosity; $\mathrm{H}_{\mathrm{T}}$ : Nei's gene diversity; $\mathrm{D}_{\mathrm{ST}}$ : diversity between breeds; $\mathrm{G}_{\mathrm{ST}}$ : coefficient of gene differentiation; HWE: significance level of Hardy-Weinberg equilibrium; $F($ Null): null allele frequency

* $P<0.05$

$\star * \star P<0.001$

The null allele frequencies in the microsatellite loci were less than $20 \%$. $D_{S T}, G_{S T}$ and $H_{T}$ were 0.068 , 0.078 and 0.879 , respectively.

Genetic diversity parameters summarized by breed are given in Table 3 . The least and greatest numbers of alleles (Na) were 9.77 (NBC) and 12.05 (AGC), respectively. The greatest expected heterozygosity $(\mathrm{He})$ was 0.86 , which was found in the EAR population. The $F_{I S}$ estimates were between 0.019 (EAR) and 0.064 (NBC). Although a total of 198 private alleles were detected, only 34 had frequencies greater than $5 \%$ (Table 3 ).

The results from the AMOVA are given in Table 4, with the greatest fraction of genotypic variation being within individuals. 
Table 3 Genetic polymorphism parameters of five Turkish cattle breeds according to 22 loci

\begin{tabular}{|c|c|c|c|c|c|c|c|c|}
\hline \multirow{2}{*}{ Breeds } & \multirow{2}{*}{$\mathrm{MNa}$} & \multicolumn{2}{|c|}{ Mean heterozigosity } & \multirow{2}{*}{$F_{I S}$} & \multirow{2}{*}{ HWE } & \multicolumn{3}{|c|}{ NPA } \\
\hline & & Ho (SE) & He (SE) & & & Freq. $\geq 5 \%$ & Freq. $<\% 5$ & Total \\
\hline NSY & 10.23 & $0.80(0.027)$ & $0.77(0.025)$ & 0.016 & 10 & - & 8 & 8 \\
\hline SAR & 9.86 & $0.75(0.037)$ & $0.77(0.018)$ & 0.056 & 16 & - & 8 & 8 \\
\hline NBC & 9.77 & $0.74(0.038)$ & $0.75(0.025)$ & 0.064 & 12 & 1 & 2 & 3 \\
\hline AGC & 12.05 & $0.88(0.022)$ & $0.85(0.008)$ & -0.006 & 8 & 18 & 24 & 42 \\
\hline EAR & 12.00 & $0.90(0.017)$ & $0.86(0.006)$ & -0.019 & 5 & 15 & 23 & 38 \\
\hline
\end{tabular}

MNa: mean number of alleles, Ho: mean observed heterozygosity, He: mean expected heterozygosity, FIS: within-breed heterozygote deficiency, HWE: number of loci exhibit deviations from HWE $(P<0.05)$, NPA: number of private alleles NSY: Native Southern Yellow; SAR: South Anatolian Red; NBC: Native Black Cattle; AGC: Anatolian Grey Cattle;

EAR: East Anatolian Red

Table 4 Distribution of genetic diversity according to Analysis of Molecular Variance

\begin{tabular}{lccccc}
\hline Source of variation & DF & SS & VC & PV (\%) & FI \\
\hline Between populations & 4 & 262.257 & $0.73805 \mathrm{Va}$ & 9.89 & $\mathrm{~F}_{\mathrm{IS}}=0.013$ \\
Within populations & 194 & 1322.489 & $0.09064 \mathrm{Vb}$ & 1.21 & $\mathrm{~F}_{\mathrm{ST}}=0.099$ \\
Within individuals & 199 & 1320.500 & $6.63568 \mathrm{Vc}$ & 88.90 & $\mathrm{~F}_{\mathrm{IT}}=0.111$ \\
\hline Total & 397 & 2905.246 & 7.46437 & &
\end{tabular}

DF: derivative free; SS: sum of squares; VC: variance component; PV: proportion of variance; FI: fixation index

These breeds were clustered into three different groups (Figure 2). The AGC and EAR breeds were on long distinct branches of the dendrogram, while NSY, SAR, and NBC breeds were closer together on a third branch. Similar groupings were obtained from the factorial correspondence analysis (FCA) (Figure 2).

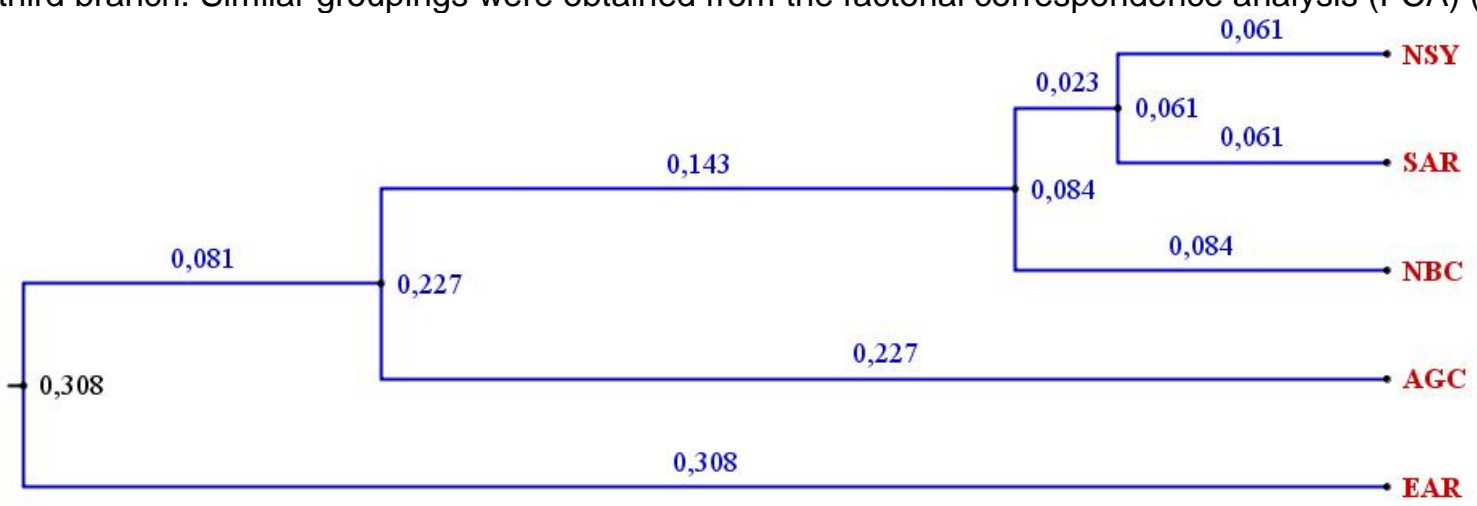

$\overbrace{0} \frac{0.04}{0.04}$

Figure 2 Dendrogram based on Nei's Da distance matrix among five native cattle breeds (bootstrap resampling methodology) (1000 replicates)

NSY: Native Southern Yellow; SAR: South Anatolian Red; NBC: Native Black Cattle; AGC: Anatolian Grey Cattle;

EAR: East Anatolian Red

The results of the population structure analysis for various numbers of ancestral clusters $(K=2-5)$ that determine the population structure are presented in Figure 3. 


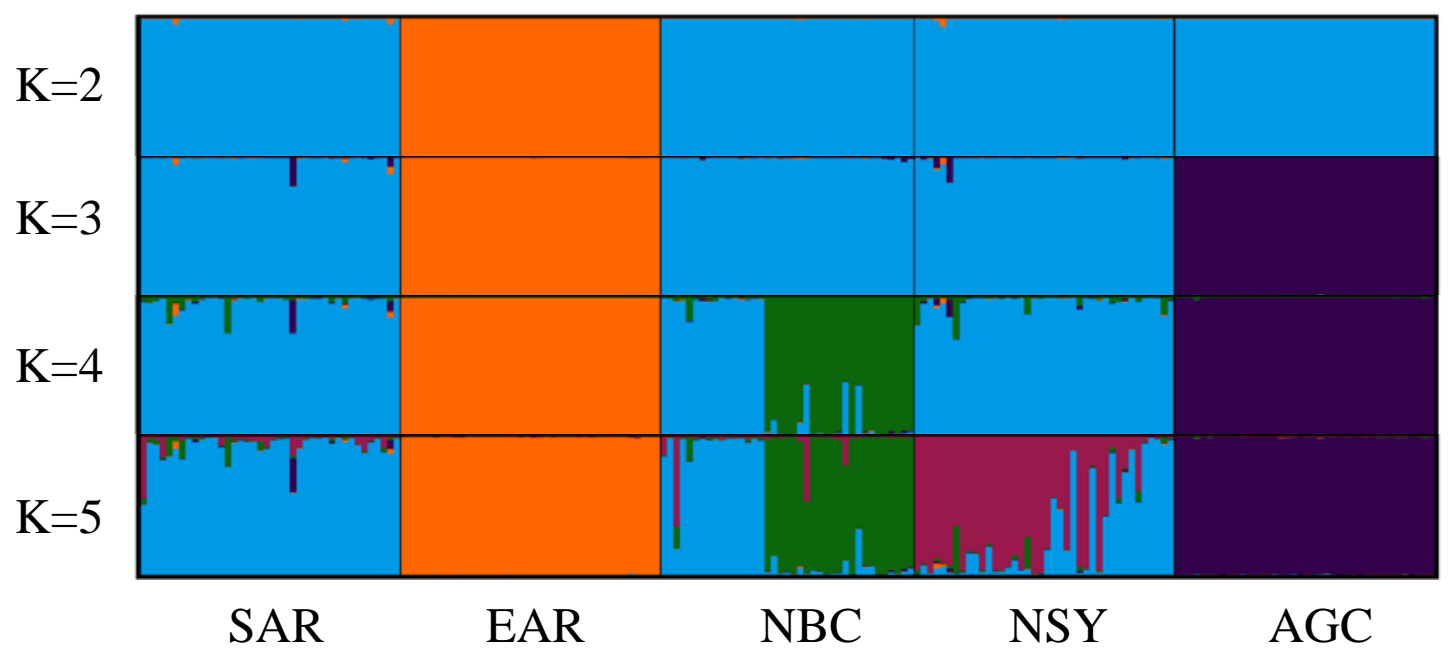

Figure 3 Estimation of the population structure with different $\mathrm{K}$ values (assuming $\mathrm{K}=2$ and 5 ) NSY: Native Southern Yellow; SAR: South Anatolian Red; NBC: Native Black Cattle; AGC: Anatolian Grey Cattle; EAR: East Anatolian Red

The results obtained from this analysis support the genetic distance dendrogram. The suitable cluster number $(K)$ identified by the STRUCTURE HARVESTER program included estimates of posterior likelihood for different $\mathrm{K}$ and $\Delta \mathrm{K}$ values. The most suitable number of ancestral groups was 3.

\section{Discussion}

Considerable genetic variation was detected within and among breeds of Turkish native cattle (Tables 2 and 3). Loftus et al. (1999) reported that genetic diversity in cattle breeds from the Near East was greater than European breeds. Total numbers of alleles and alleles per locus were greater than previously reported for native cattle from Brazil (22 microsatellite markers, 278 alleles) (Egito et al., 2007), Turkey (20 microsatellite markers, 274 alleles) (Özşensoy et al., 2010), Korea (30 microsatellite markers, 276 alleles) (Suh et al., 2014) Indian (21 microsatellite markers,359 alleles) (Sharma et al., 2015), and South Africa (22 microsatellite markers, 199 alleles) (Sanarana et al., 2016). The MNa were fewer for SAR (9.86), NBC (9.77) than was observed by Özşensoy et al. (2010) with 11 loci. However, MNA for NSY (10.80), AGC (12.55), and EAR (12) were greater than in the previous study (Özşensoy et al., 2010). MNA were also greater than had been observed by Loftus et al. (1999) for Turkish native breeds of cattle. It could be said that Turkish native cattle breeds are genetically diverse.

The $F_{I S}$ values for the overall populations suggest a moderate level of gene flow between breeds. Low $F_{\text {IS }}$ values for each breed revealed high heterogeneity in Turkish native cattle breeds, and the highest $F_{I S}$ value of 0.064 was observed in the NBC breed. Similar findings for this breed were reported by Özşensoy (2011) and Semen et al. (2019). Negative $F_{I S}$ values (Table 3) may refer to heterozygote excess (Shane, 2005).

All microsatellites have values below $20 \%$, which is the critical value for null allele frequency. The presence of null alleles, which are defined as non-amplifying alleles owing to mutations at PCR priming sites, causes overestimation of both $\mathrm{F}_{\mathrm{ST}}$ and genetic distance values (Dakin \& Avise, 2004).

The average $\mathrm{G}_{\mathrm{ST}}$ value obtained from the overall loci pointed out that $7.8 \%$ of total genetic variation resulted from the differences between the populations. Thus, $92.2 \%$ genetic variation resides among individuals within populations. The overall genetic diversity $\left(D_{\mathrm{ST}}\right)$ estimated in the present study was another indication that inter-population variability is not great.

Nei's gene diversity $\left(\mathrm{H}_{\mathrm{T}}\right)$ value was 0.879 , which was greater than estimates from Swiss breeds (Schmid et al., 1999) and Hanwoo cattle (Yoon et al., 2005), but lower than for Kenkatha cattle raised in Asia (Pandey et al., 2006). Greater genetic diversity is an expected phenomenon in populations that originated near a centre of domestication (Loftus et al., 1999).

The visual representation of genetic distances as a dendrogram and STRUCTURE results were in agreement. Thus, the NSY, SAR and NBC populations are probably related and separate from the more distinct AGC and EAR breeds. Gene flows between NSY, SAR and NBC breeds can also be gleaned from the STRUCTURE HARVESTER results. The lack of private alleles in SAR and NSY may be an indicator of gene flow between them. Similar clustering was observed in studies carried out by mtDNA (Özdemir \& Doğru, 2017; Doğan et al., 2017) and autosomal microsatellite markers (Özşensoy et al., 2010) analyses. 
However, investigation of Turkish native cattle breeds by RAPD and $Y$ chromosomal markers revealed a different phylogeny for these breeds (Özşensoy et al., 2014; Güneren et al., 2010). According to Y chromosomal markers, NSY, AGC and EAR were most related (Özşensoy et al., 2014).

\section{Conclusions}

Future population structures and sustainability will be determined by processes that shape the current population. Thus, monitoring and maintaining genetic diversity is important for breeds of cattle to survive. Turkish native cattle breeds have substantial genetic variation and contribute to the genetic diversity of the world's cattle. To meet future needs, this diversity should be maintained. Little research has focused on within-breed genetic variation in breeds of cattle that are native to Turkey. Native populations should be monitored regularly using molecular markers, and conservation strategies should be updated according to population parameters obtained from these studies. In addition to results from molecular studies, more morphological and phenotypic data should be integrated into breeding and conservation programmes.

\section{Acknowledgements}

This work was financially supported by the Scientific Research Council of Uludag University (Project number KUAP 2015/80). The authors acknowledge the Agricultural Biotechnology and Food Safety Application and Research Centre (ADÜ-TARBIYOMER) of Adnan Menderes University for providing laboratory facilities for molecular genetics analyses. This manuscript was edited by American Journal Experts (AJE).

\section{Authors' Contributions}

YO, OY and SK designed the study, CU and CE collected blood sample and DNA isolation, respectively. OY, YO and NA performed the molecular genetic analysis, OY and SK performed molecular genetic statistics, YO, OY and SK wrote the paper with input from all authors.

\section{Conflict of Interest Declaration}

The authors declare that they have no conflict of interest.

\section{References}

Dakin, E.E. \& Avise, J.C., 2004. Microsatellite null alleles in parentage analysis. Heredity 93, 504-509.

Diamond, J., 1997. Guns, Germs, and Steel. Norton, New York, NY, USA.

Doğan, M., Nizamlıŏlu, M., Özşensoy, Y., Kurar, E., Bulut, Z., Altunok, V., ışık, A. \& Çamlıdağ, A., 2017. Maternal phylogenetics of some Anatolian cattle breeds. Univers. J. Agr. Res. 5(2),79-84.

Earl, D.A. \& Vonholdt, B.M., 2012. STRUCTURE HARVESTER: A website and program for visualizing STRUCTURE output and implementing the Evanno method. Conserv. Genet. Resour. 4, 359-361.

Egito, A.A., Paiva, S.R., Albuquerque, M.D.S.M., Mariante, A.S., Almeida, L.D., Castro, S.R. \& Grattapaglia, D., 2007. Microsatellite based genetic diversity and relationships among ten Creole and commercial cattle breeds raised in Brazil. BMC Genet. 8, 83.

Evanno, G., Regnaut, S. \& Goudet, J., 2005. Detecting the number of clusters of individuals using the software STRUCTURE: A simulation study. Mol. Ecol. 14, 2611-2620.

Excoffier, L. \& Lischer, H.E.L., 2010. Arlequin suite version 3.5, A new series of programs to perform population genetics analyses under Linux and Windows. Mol. Ecol. Resour. 10, 564-567.

FAO, 2018. Biodiversity of Turkey: Contribution of genetic resources to sustainable agriculture and food systems. Ankara. 222 pp. Licence: CC BY-NC-SA 3.0 IGO.

Falush, D., Stephens, M. \& Pritchard, J.K., 2003. Inference of population structure using multilocus genotype data: Linked loci and correlated allele frequencies. Genetics 164, 1567-1587.

Falush, D., Stephens, M., Pritchard, J.K., 2007. Inference of population structure using multilocus genotype data: Dominant markers and null alleles. Mol. Ecol. Notes 7, 574-578.

FAO 2011. Molecular genetic characterization of animal genetic resources. FAO, Rome.

Goudet, J., 2001. FSTAT, a program to estimate and test gene diversities and fixation indices (version 2.9. 3). Available at http://www.unil.ch/popgen/softwares/fstat.htm. Accessed 2 March 2005

Glazko, V., 2013. An attempt at understanding the genetic basis of domestication. Anim. Sci. Pap. Rep. 21, $109-120$.

Güneren, G., Akyüz, B. \& Ertugrul, O., 2010. Use of RAPD-PCR for genetic analyses on the native cattle breeds in Turkey. Ankara Univ. Vet. Fak. 57, 167-172.

Hecker, K.H. \& Roux, K.H., 1996. High and low annealing temperatures increase both specificity and yield in touchdown and stepdown PCR. Biotechniques 20, 478-485.

Hubisz, M.J., Falush, D., Stephens, M. \& Pritchard, J.K., 2009. Inferring weak population structure with the assistance of sample group information. Mol. Ecol. Resour. 9, 1322-1332.

Kalinowski, S.T., Taper, M.L. \& Marshall, T.C., 2007. Revising how the computer program CERVUS accommodates genotyping error increases success in paternity assignment. Mol. Ecol. 16, 1099-1106.

Kopelman, N.M., Mayzel, J., Jakobsson, M., Rosenberg, N.A. \& Mayrose, I., 2015. Clumpak: A program for identifying clustering modes and packaging population structure inferences across K. Mol. Ecol. Resour. 15, 1179-1191.

Langella, O., 1999. Populations 1.2.32. Population Genetic Software. Gif-sur-Yvette, France: Laboratoire Evolution, Génomes et Spéciation. Available at: http://bioinformatics.org/tryphon/populations/. Accessed 9 July 2015. 
Loftus, R.T., Ertugrul, O., Harba, A.H., El-Barody, M.A.A., Machugh, D.E.S., Park, D.E. \& Bradley, D.G., 1999. A microsatellite survey of cattle from a centre of origin: the Near East. Mol. Ecol. 8, 2015-2022.

Marshall, T.C., Slate, J., Kruuk, L.E.B. \& Pemberton, J.M., 1998. Statistical confidence for likelihood-based paternity inference in natural populations. Mol. Ecol. 7, 639-655.

Nei, M., Tajima, F. \& Tateno, Y., 1983. Accuracy of estimated phylogenetic trees from molecular data .2. Gene-frequency data. J. Mol. Evol. 19, 153-170.

Notter, D.R., 1999. The importance of genetic diversity in livestock populations of the future. J. Anim. Sci. 77, 61-69.

Özdemir, M. \& Doğru, Ü., 2009. Determination of phylogenetic relationships of Turkish native cattle breeds with other cattle breeds using mitochondrial DNA D-loop sequence polymorphism. Asian-Australas. J. Anim. 22, 955-961.

Özkan, E., 2005. An investigation on genetic structure of native and cultural cattle breeds in Turkey by using microsatellite markers. Thesis (PhD), Trakya University, Tekirdağ, Türkiye.

Özşensoy, Y., 2011. Genetic characterization of some Turkish cattle breeds. Doctoral dissertation, Institute of Health Sciences, Selcuk University, Konya, Turkey.

Özşensoy, Y., Kurar, E., Doğan, E., Bulut, Z., Altunok, V., Işık, A., Çamlıdağ, A. \& Nizamlığlu, A., 2010. Türkiye'de bulunan bazi yerli siğir irklarinin STR markörler ile genetik karakterizasyonu. Res. J.Biol. Sci. 3, 163-171. (in Turkish with an English abstract)

Özşensoy, Y., Kurar, M., Bulut, Z. \& Nizamlioğlu, M., 2014. Y chromosome analysis of native Turkish cattle breeds by microsatellite markers. Turkish J. Biol. 38, 388-395.

Pandey, A.K., Sharma, R., Singh, Y., Prakash, B. \& Ahlawat, S.P.S., 2006. Evaluation of genetic variability in Kenkatha cattle by microsatellite markers. Asian-Australas. J. Anim. 19, 1685-1690.

Peakall, R. \& Smouse, P.E., 2006. GENALEX 6: Genetic analysis in Excel. Population genetic software for teaching and research. Mol. Ecol. Notes 6, 288-295.

Peakall, R. \& Smouse, P.E., 2012. GenAlEx 6.5: genetic analysis in Excel. Population genetic software for teaching and research - an update. Bioinformatics 28, 2537-2539

Price, T.D., 2000. Europe's First Farmers: An introduction. Cambridge University Press, Cambridge, UK.

Pritchard, J.K., Stephens, M. \& Donnelly, P., 2000. Inference of population structure using multilocus genotype data. Genetics 155, 945-959.

Rambout, A., 2006. FigTree 1.4.2. Available at: § http://tree.bio.ed.ac.uk/. Accessed: 09 July 2015.

Sanarana, Y., Visser, C., Bosman, L., Nephawe, K., Maiwashe, A. \& Van Marle-Köster, E., 2016. Genetic diversity in South African Nguni cattle ecotypes based on microsatellite markers. Trop. Anim. Health Prod. 48, 379-85.

Schmid, B.M., Saitbekova, N., Gaillard, C. \& Dolf, G., 1999. Genetic diversity in Swiss cattle breeds. J. Anim. Breed Genet. 116 (1), 1-8.

Semen, Z., Karakaş, V., Çökülgen, T., Ünal, İ. \& Yılmaz, O., 2019. Bottleneck analysis of Anatolian Black Cattle (Bos taurus) using microsatellite markers. Agrofor Int. J. 4 (1), 161-168.

Shane, S., 2005. Shane's simple guide to F-statistics. University of Auckland, Auckland, New Zealand. 21.

Sharma, R., Kishore, A., Manishi, M., Ahlawat, S., Maitra, A., Pandey, A.K. \& Tantia, M.S., 2015. Genetic diversity and relationship of Indian cattle inferred from microsatellite and mitochondrial DNA markers. BMC Genet. 16, 73.

Suh, S., Kim, Y.S., Cho, C.Y., Byun, M.J., Choi, S.B., Ko, Y.G., Lee, C.W., Jung, K.S., Bae, K.H. \& Kim, J.H., 2014. Assessment of genetic diversity, relationships and structure among Korean Native cattle breeds using microsatellite markers. Asian-Australas. J. Anim. 27, 1548-1553.

Toro, M.A. \& Caballero, A., 2005. Characterization and conservation of genetic diversity in subdivided populations. Philos. T. R. Soc. B. 360 (1459), 1367-1378.

Weir, B.S. \& Cockerham, C.C., 1984. Estimating F-statistics for the analysis of population structure. Evolution 38, 13581370.

Wright, S., 1990. Evolution in Mendelian populations (reprinted from Genetics 16 (1931), 97-159). Bull. Math. Biol. 52, 241-295.

Yeh, F.C., Yang, R. \& Boyle, T., 1997. POPGENE version 1.32. Molecular Biology and Biotechnology Centre, University of Alberta, and Centre for International Forestry Research, Canada.

Yoon, D.H., Kong, H.S., Oh, J.D., Lee, J.H., Cho, B.W., Kim, J.D., Jeon, K.J., Jo, C.Y., Jeon, G.J. \& Lee, H.K., 2005. Establishment of an individual identification system based on microsatellite polymorphisms in Korean cattle (Hanwoo). Asian-Australas. J. Anim. 18, 762-766.

Zeder, M.A., 2008. Domestication and early agriculture in the Mediterranean Basin: Origins, diffusion, and impact. Proc. Natl. Acad. Sci. U.S.A 105 (33), 11597-11604. 